\title{
Comparative Pathogenicity of Colletotrichum spp. Against Different Varieties of Strawberry Plants (Fragaria ananassa) Widely Grown in Morocco
}

\author{
H. EL KAISSOUMI, N. MOUDEN, M. CHLIYEH, R. BENKIRANE, \\ A. OUAZZANI TOUHAMI and A. DOUIRA* \\ Laboratory of Botany Biotechnology and Plant Protection, Department of Biology, \\ Faculty of Sciences BP. 133, Ibn Tofail University, Kenitra, Morocco
}

(Received: 4 March 2018; accepted: 18 April 2018)

\begin{abstract}
The evolution of anthracnose symptoms on the aerial part (leaves, stems and strawberries) of three varieties Fortuna, Camarosa and Festival of strawberry plants inoculated with the conidial suspensions of Colletotrichum acutatum and Colletotrichum gloeosporioides isolates was followed. The severity index and infection coefficients increased in function of time. Seven days after inoculation they were low not exceeding $13.43 \%$ and 43.33 , but they increased four weeks after inoculation, respectively, to $37.96 \%$ and 99 on strawberry plants of the Camarosa variety, $54.44 \%$ and 105 on those of Fortuna and $51.12 \%$ and 85 on those of Festival. At the sixth week, the severity index and infection coefficients became very high, reaching respectively $100 \%$ and 408 on Fortuna plants inoculated with C. gloeosporioides isolate (Coll3) followed by Coll2 (89.28\% - 300), Coll1 (86.66\% - 378) and Coll4 (80.45\% - 198) of C. acutatum species. Similarly, the isolate Coll3 caused fruit rot; the percentage of rotten strawberries was $100 \%$ on Fortuna variety, $83.33 \%$ on Festival and $70.25 \%$ on Camarosa. A positive re-isolation of the tested Colletotrichum isolates has been noted from leaves of strawberry varieties and negative from crowns or the roots. A significant to moderate reduction in fresh and dry weights of the aerial part and roots was noted in inoculated strawberry plants compared to the control.
\end{abstract}

Keywords: Colletorichum spp., strawberry plant, pathogenecity, symptoms.

The strawberry (Fragaria $\times$ ananassa Duchense ex Rozier) is considered the most economically important berry worldwide (Hummer and Hancock, 2009). Developed in Europe in 1766 (Darrow, 1966), Fragaria $\times$ ananassa Duchesne has diversified over time into several varieties and cultivars. In particular, characteristics such as productivity, disease resistance, fruit firmness, freezing quality, sugar and acid content, flower color, habit of flowering, berry taste, size, color and shape are important for selection of strawberry cultivars (Kosar et al., 2004; Voca et al., 2009; Winardiantika et al., 2015).

Strawberry (Fragariaxananassa Duch.) can be cultivated in the open field as a perennial or annual crop (Galletta and Bringhurst, 1990; Rubio et al., 2014). However, high-tunnels could mitigate some phytosanitary problems by reducing the free water on the plants and fruits (Jensen and Malter, 1995; Lamont, 2009; Grijalba et al., 2015). Protected culture systems such as greenhouses and tunnels are becoming more popular for the

* Corresponding author; e-mail: douiraallal@gmail.com 
protection against frost (Neri et al., 2012), extension of the harvest period and increased yields (Lieten and Baetes, 1991; Grijalba et al., 2015), fruit quality improvement (Xiao et al., 2001; Kadir et al., 2006) as well as control of several major plant diseases (Xiao et al., 2001; Evenhuis and Wanten, 2006). Indeed, in warmer regions like California, Florida and the Mediterranean region greenhouse and tunnel strawberry production is as extensive as open fields (Delp and Milholland, 1981; Howard et al., 1992; Tanji et al., 2014; Anonymous, 2015). Concerning the conventional fruit production is based on annual planting of bare-root green plants placed in two rows into beds protected by opaque plastic mulch with localized irrigation equipment, fertilizing irrigation system and covered by macrotunnels with clear mulch (López-Aranda, 2008).

In Morocco, Gharb and Loukkos are Morocco's leading strawberry producer regions with acreage of about 3500 ha (Anonymous, 2014). The most cultivated strawberry varieties in Morocco are derived from California (Atta Aly and Ezzat, 1999). In 2013, producers were interested in planting many varieties like Camarosa, Festival, Splendor, Fortuna, Lusa, Magdalena, Sabrina, San Andreas, Venicia and Ventana but the dominant role is still played by the first four varieties (Tanji et al., 2014).

Otherwise, the growth of strawberry has increased during last decades however its productivity is still low compared to other developing countries (Anonymous, 2017). There are several reasons for it; mostly yield losses can be caused both by unfavorable environment conditions and due to damage by different pathogenic organisms (Wittwer and Castilla, 1995; Xiao et al., 2001; Jiang et al., 2003). The strawberry crop can be attacked by viruses (Martin et al., 2004; Li and Yang, 2011), bacteria (Mdarhri, 2005; Anonymous, 2006; Bull et al., 2009), mites (Zahdali, 2003; Lagziri and El Amrani, 2009), nematodes (Lamindia, 2002), pests (Nicolov, 2006), weeds (Lansari, 1985), and fungi (Paulus, 1990; Maas, 1998) including soil-borne pathogens and aerial ones. Indeed fungal species cause serious pathologies afflicting host damage and a considerable reduction of the yield (Sreenivasaprasad and Talhinhas, 2005; Abdel-Sattar et al., 2008; Fang et al., 2012; Ceja-Torres et al., 2014).

Colletotrichum is among ten most important plant pathogenic fungi (Dean et al., 2012). The genus Colletotrichum is highly recognized as anthracnose disease agent on strawberry (De Los Santos et al., 2003). This disease represents a potential threat and a disease of great importance whose causative agent is only the fungal complex including C. acutatum J. H. Simmonds, C. gloeoporioides (Penz.) Penz. and Sacc. (teleomorph Glomerella cingulata (Stoneman) Spauld. and H. Schrenk) and C. fragariae Brooks (Smith, 1986; Smith and Black, 1990; Gunnell and Gubler, 1992; Howard et al., 1992; Denoyes and Baudry, 1995; Freeman and Katan, 1997; Legard, 2000; De Los Santos et al., 2003; Talubnak and Soytong, 2010 ). Symptoms associated with Colletotrichum infection include crown rot (Horn and Carver, 1962; Mangandi et al., 2015) fruit rot (Howard, 1972; Urena-Padilla et al., 2002), root necrosis (Freeman and Katan, 1997), black spots on leaves (Howard and Albregts, 1983), petioles and runners (Delp and Milholland, 1981).

Indeed, Colletotrichum gloeosporioides and Colletotrichum acutatum are distributed worldwide on a number of hosts such as kernels (Ogawa and English, 1991; Adaskaveg and Hartin, 1997; Förster and Adaskaveg, 1999), avocado (Freeman, 2000; Akgül et al., 2016), peach (Adaskaveg and Hartin, 1997; Zaitlin et al., 2000), blueberries (Smith et al., 1996; Schilder et al., 2001; Yoshida and Tsukiboshi, 2002), citrus (Zulfiqar et al., 1996; Timmer and Brown, 2000; Benyahia et al., 2003), mango (Fitzell, 1979; Arauz, 
2000), olive tree (Martin and García-Figueres, 1999; Benyahia et al., 2003; Chattaoui et al., 2016; Msairi et al., 2017), while Colletotrichum fragariae has a very narrow range of hosts (Mackenzie et al., 2006). A typical anthracnose symptom on cultivated strawberry caused by $C$. acutatum and $C$. gloeosporioides was reported in Egypt (Embaby et al., 2009). In Europe, $C$. acutatum is the most prevalent species causing anthracnose, whereas $C$. gloeosporioides is found only occasionally, and $C$. fragariae has not yet been observed (Denoyes and Baudry, 1995; Garrido et al., 2008). In UK, the first incidence of anthracnose disease in strawberries caused by $C$. acutatum was attributed to the importation of infected strawberry runners from the USA (Calleja et al., 2012). These fungal species affects fruit quality and causes significant pre- and post-harvest fruit losses, especially during wet weather (Prusky and Plumbey, 1992; Prusky, 1996; Arauz, 2000; Chrys, 2006). In Belgian strawberry production fields, fruit losses caused by Colletotrichum can easily rise above $25 \%$, even after repeated treatment with fungicides (Van Hemelrijck et al., 2010). An epidemic proportion in Israeli nurseries and production fields was reached by strawberry anthracnose (Freeman and Katan, 1997) in addition to severe outbreaks of fruit rot which have been developed in the United States after the apparent introduction of Colletotrichum acutatum in the 1980s (Smith, 1986; Howard et al., 1992).

In Morocco, the occurrence of Colletotrichum species was represented by $C$. acutatum and C. gloeosporioides encountered in two strawberry farms in the locality of Moulay Bousselham (Gharb-Loukkos, North West Morocco) during surveys carried out in 2010 (Mouden et al., 2013). They were also appeared on the aerial parts of four varieties grown at different strawberry plantations of the Gharb-Loukkos during crop season 2012-2013 (Mouden et al., 2016). On the other hand, under laboratory conditions, one of the identified $C$. gloeosporioides isolates had the capacity to cause necrosis on detached leaves of Festival and Splendor varieties (Mouden, 2015). According to Han et al. (2016), the frequencies and distribution of Colletotrichum species are related to differences in high temperature tolerance and pathogenicity.

Thus, performing pathogenicity tests of different isolates of Colletotrichum species is required before determination of isolates aggressiveness, the risk evaluation of spread and disease development. The primary objective of this work was to study the pathogenicity of $C$. acutatum and $C$. gloeosporioides on different varieties of strawberry plants widely grown in Morocco.

\section{Materials and Methods}

\section{Fungal material}

Four isolates were used; three of them represent Colletotrichum acutatum (Coll1, Coll2 and Coll4). They were isolated, respectively, from a strawberry of Camarosa variety, stem of Festival variety and the crown of Camarosa variety. The fourth isolate represents Colletotrichum gloeosporioides (Coll3) was isolated from the crown of the Camarosa variety. The culture of four isolates were grown on PSA medium (Potato: $200 \mathrm{~g}$, Sucrose: 20 g, Agar-agar: $15 \mathrm{~g}$, Distilled water: $1000 \mathrm{~mL}$ ) at $24{ }^{\circ} \mathrm{C}$ in the dark for seven days. 


\section{Plant material}

Bare-root strawberry transplant of the Fortuna variety, Festival and Camarosa varieties were grown in pots containing 50\% black peat and 50\% of Mamora soil (Physicochemical parameters: $\mathrm{pH}$ : 7.53; Organic matter: 0.7\%; Nitrogen: 0.05\%; Phosphorus $\left(\mathrm{P}_{2} \mathrm{O}_{5}\right): 0.239 \%$; Potassium $\left(\mathrm{K}_{2} \mathrm{O}\right): 0.15 \mathrm{meq} / 100 \mathrm{~g}$; Magnesium $(\mathrm{Mg}): 0.20 \mathrm{meq} / 100 \mathrm{~g}$; Calcium (Ca): 7351.5 (meq/100 g), placed in a greenhouse and daily watered until to the stage of five leaves required for inoculation.

\section{Inoculation}

Conidial suspensions of Colletotricum isolates were prepared by flooding fully grown potato dextrose agar (PDA) 7 days old cultures with sterile distilled water and display the surface with a glass rod. The mixture was filtered through muslin cloth into a flask with sterile distilled water containing a single drop of Tween 20 and gelatin $0.05 \%$. The final concentration of the suspension was adjusted to $10^{5}$ conidia $/ \mathrm{mL}$ using the hemocytometer. Approximately, $30 \mathrm{~mL}$ of the conidial suspension was sprayed to runoff directly to the aerial parts of the three strawberry varieties by hand-pressurized atomizer. Plants using as control were inoculated with distilled water containing $0.05 \%$ Tween 20 and gelatin $0.05 \%$. The inoculated plants were packed for 72 hours in plastic wrap to maintain the necessary humidity and exposure to moisture leaves for growth of the pathogen and then placed in a greenhouse. The experimental protocol was designed in random blocks with three replicates for each isolate and one plant per pot.

\section{Disease evaluation}

The symptoms appearance was followed during 6 weeks and evaluated in terms of both disease severity (extent of diseased leaf area) and disease incidence (number of leaves with symptoms).

\section{Disease severity index}

From the first week to the sixth after inoculation, the diseased leaf area was estimated according to the scale of Stover modified by Gauhl et al. (1995): degree $0=$ no symptoms; degree $1=$ less than $0.5 \%$ of the leaf showing symptoms; degree $2=0.6$ to $5 \%$ of the leaf with symptoms; degree $3=6$ to $15 \%$ of the leaf with symptoms; degree $4=16$ to $30 \%$ of the leaf with symptoms; degree $5=31$ to $50 \%$ of the leaf with symptoms; degree $6=51$ to $80 \%$ of the leaf with symptoms; degree $7: 81$ to $100 \%$ of the leaf with symptoms.

The disease severity index (SI) was calculated according to the following formula:

$$
\mathrm{SI}(\%)=\frac{\Sigma \mathrm{nb}}{(\mathrm{N}-1) \times \mathrm{T}} \times 100
$$

$\mathrm{n}=$ number of leaves for each degree of the scale;

$\mathrm{b}=$ degree of the arbitrary scale representing the severity;

$\mathrm{N}=$ number of degrees used in the scale;

$\mathrm{T}=$ total number of leaves evaluated. 


\section{Coefficient of infection}

The coefficient of infection (IC) was calculated by multiplying the incidence by the disease severity.

\section{$\mathrm{IC}=$ Severity $\times$ Incidence}

Severity: degree of scale.

Incidence: total number of leaves with symptoms.

\section{Strawberry responses to Colletotrichum isolates}

Strawberry infections were scored every week by counting the total number of fruits showing anthracnose rot among total number of strawberries produced by each strawberry plant in function of time and determining the percentage of strawberries showing anthracnose fruit rot.

\section{Agronomic parameters}

At the end of the trials, the plants were gently taken off from their culture substrate and washed under a running water to remove adhering soil particles. The aerial part of each plant was cut at the collar, the fresh weights of the aerial part and the roots of the strawberry plants were measured using a precision balance. The dry weight of the aerial part and roots were also weighed after drying in an oven at $70{ }^{\circ} \mathrm{C}$ for 24 hours.

\section{Re-isolation}

The leaves, crowns and roots of the three varieties of strawberry inoculated with the four isolates of Colletotrichum and the control plants were cut into small pieces (of $1 \mathrm{~cm}^{2}$ for leaves and $1 \mathrm{~cm}$ in lengh for stems and roots) and then placed in alcohol at $95{ }^{\circ} \mathrm{C}$ for 2 min, rinsed with sterile distilled water several times and dried on sterile filter paper. The fragments were planted in PSA medium amended with $50 \mathrm{mg}$ Streptomycin. The Petri dishes were incubated in the darkness at $22{ }^{\circ} \mathrm{C}$. After 10 to 14 days, the colonies were identified. The re-isolation percentage $(\mathrm{Pr} \%)$ was obtained by applying the following formula:

$$
\operatorname{Pr}=\mathrm{Ns} \text { Px } / \mathrm{NT} \times 100
$$

Ns Px: number of segments containing the fungal species $\mathrm{x}$.

NT: total number of segments.

\section{Statistical analysis}

The statistical treatment of the results obtained was performed according to the generalized linear model (GLM) by comparison of means, according to the LSD test at the 5\% threshold. The analyses were based on the averages attributed to the effect of each isolate on strawberry plant varieties as a function of time. 


\section{Results}

The examination of the aerial plant parts showed the ability of the tested Colletotrichum acutatum and Colletotrichum gloeosporioides isolates infecting vigorously the vegetative tissues of the three inoculated varieties of strawberry plants. The post-inoculation infections caused various disorders affecting the production of strawberry plants (devel-
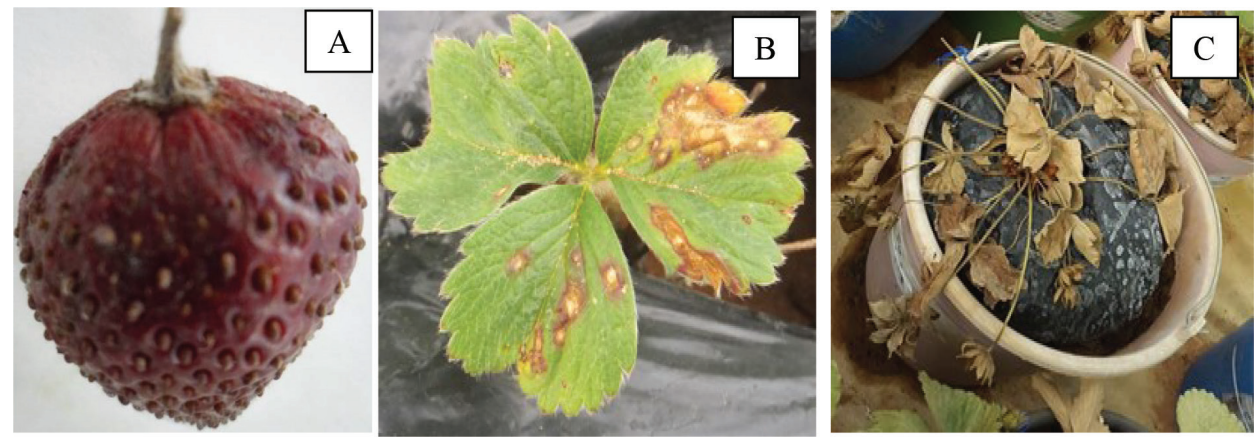

Fig. 1. Symptoms developed on a young strawberry (A), leaves (B), strawberry plant (C) after inoculation with Colletotrichum isolates

Table 1

Evolution of the severity index (SI\%) of the disease in strawberry plants inoculated with Colletotrichum isolates according to time

\begin{tabular}{|c|c|c|c|c|c|c|}
\hline $\begin{array}{l}\text { Time } \\
\text { (per } \\
\text { week) }\end{array}$ & Varieties & Control & Coll1 & Coll2 & Coll3 & Coll4 \\
\hline \multirow{3}{*}{1} & Camarosa & $0.00^{\mathrm{w}}$ & $3.45^{\mathrm{vw}}$ & $0^{\mathrm{w}}$ & $10.49^{\text {rstuvw }}$ & $0^{\mathrm{w}}$ \\
\hline & Fortuna & $0.00^{\mathrm{w}}$ & $8.33^{\text {stuvw }}$ & $7.57^{\text {stuvw }}$ & $13.43^{\text {pqrstuvw }}$ & $3.08^{\mathrm{vw}}$ \\
\hline & Festival & $0.00^{\mathrm{w}}$ & $4.49^{\mathrm{uvw}}$ & $10.20^{\text {qrstuvw }}$ & $13.12^{\text {rstuvw }}$ & $9.04^{\text {stuvw }}$ \\
\hline \multirow{3}{*}{2} & Camarosa & $0.00^{\mathrm{w}}$ & $10.51^{\text {rstuvw }}$ & $6.45^{\mathrm{stuvw}}$ & $18.72^{\text {nopqrstuv }}$ & $14.77^{\text {opqrstuvw }}$ \\
\hline & Fortuna & $0.00^{\mathrm{w}}$ & $14.15^{\text {pqrstuvw }}$ & $9.62^{\text {stuvw }}$ & $25.58^{\mathrm{klmnopqrs}}$ & $9.87^{\text {stuvw }}$ \\
\hline & Festival & $0.00^{\mathrm{w}}$ & $19.52^{\text {mnopqrstuv }}$ & $18.23^{\text {nopqrstuvw }}$ & $22.80^{1 \mathrm{mnnopqrst}}$ & $19.16^{\text {nopqrstuv }}$ \\
\hline \multirow{3}{*}{3} & Camarosa & $0.00^{\mathrm{w}}$ & $35.44^{\mathrm{klmn}}$ & $11.11^{\text {rstuvw }}$ & $36.70^{\mathrm{klmn}}$ & $17.68^{\text {npqrstuvw }}$ \\
\hline & Fortuna & $0.00^{\mathrm{w}}$ & $21.74^{\text {lmnopqrstu }}$ & $10.89^{\text {rstuvw }}$ & $35.60^{\mathrm{klmn}}$ & $22.01^{\text {lmnopqrstu }}$ \\
\hline & Festival & $0.00^{\mathrm{w}}$ & $19.27^{\text {nopqrstuv }}$ & $30.74^{\mathrm{klmn}}$ & $44.06^{\text {ghij }}$ & $34.95^{\mathrm{klmn}}$ \\
\hline \multirow{3}{*}{4} & Camarosa & $0.00^{\mathrm{w}}$ & $36.98^{\mathrm{jklmn}}$ & $28.33^{\mathrm{klmnopqr}}$ & $37.96^{\mathrm{jklm}}$ & $37.65^{\mathrm{jklm}}$ \\
\hline & Fortuna & $0.0^{\mathrm{w}}$ & $33.54^{\mathrm{klmn}}$ & $30.77^{\mathrm{klmnopq}}$ & $54.44^{\text {defghij }}$ & $31.66^{\mathrm{klmnop}}$ \\
\hline & Festival & $0.00^{\mathrm{w}}$ & $42.77^{\text {ghij }}$ & $34.36^{\mathrm{klmn}}$ & $51.12^{\text {efghij }}$ & $39.21^{\mathrm{ijkl}}$ \\
\hline \multirow{3}{*}{5} & Camarosa & $0.00^{\mathrm{w}}$ & $41.01^{\text {ghij }}$ & $32.56^{\mathrm{klmno}}$ & $46.2^{\text {fghij }}$ & $39.17^{\mathrm{ijkl}}$ \\
\hline & Fortuna & $0.00^{\mathrm{w}}$ & $54.06^{\text {defghij }}$ & $57.10^{\text {defghi }}$ & $70.97^{\mathrm{cd}}$ & $64.25^{\text {def }}$ \\
\hline & Festival & $0.00^{\mathrm{w}}$ & $52.17^{\text {efghij }}$ & $40.62^{\text {hijk }}$ & $57.78^{\text {defgh }}$ & $53.33^{\text {defghij }}$ \\
\hline \multirow{3}{*}{6} & Camarosa & $0.00^{\mathrm{w}}$ & $51.07^{\text {fghij }}$ & $46.31^{\text {ghij }}$ & $60.98^{\text {defg }}$ & $43.98^{\text {ghij }}$ \\
\hline & Fortuna & $0.00^{\mathrm{w}}$ & $86.66^{\mathrm{abc}}$ & $89.28^{\mathrm{ab}}$ & $100^{\mathrm{a}}$ & $80.45^{\text {bcd }}$ \\
\hline & Festival & $0.00^{\mathrm{w}}$ & $53.33^{\text {defghij }}$ & $61.25^{\text {defgh }}$ & $66.69^{\text {cde }}$ & $44.16^{\text {ghij }}$ \\
\hline
\end{tabular}

Any two data in a table followed by the same letter are not statistically different at $5 \%$ 
opment of vegetative and root biomasses of strawberry plants). The younger strawberries present abnormal growth and anthracnose symptoms appeared as brown necrotic tissues with round lesions of 2 to $3 \mathrm{~mm}$ covering fruits (Fig. 1A).

Symptom expression on leaves was characterized by brown spots, circular or oval in shape at the center and surrounded by a yellow halo of 1 to $2 \mathrm{~mm}$ (Fig. 1B). In advanced stages of lesion development, symptoms on leaves appear as dry, brown lesions develop along the margins and the leaves extremities (Fig. 1B). Then leaf blight and wilting were observed. Also, oval spots slightly depressed in the center and dark in color were formed on the petioles, peduncles and pedicels. The strong attacks of Colletotrichum isolates led to the leaves death and senescence of all strawberry plants in case of Fortuna variety (Fig. 1C and Fig. 3B).

In function of time, the progressive symptoms appearance expressed by evolution of severity index (Table 1) and infection coefficients (Table 2) of the tested Colletotrichum isolates on strawberry plants varieties was marked by a significant increase.

Seven days after inoculation, disease severity index and infection coefficients were low for all varieties and did not exceed $13.43 \%$ and 43.33 , respectively. No statistical differences in severity index were found by the evaluation of all isolates in the varieties whereas the infection coefficient of Coll3 on Festival variety was significantly different from those of Coll1, Coll2 and Coll4. After four weeks, Coll3 exhibited the highest level of severity index and infection coefficients reaching respectively, 54.44\% and 105 on Fortuna variety. A notable increase of virulence degree was checked in six weeks after

Table 2

Evolution of the infection coefficient (IC) in strawberry plants inoculated with Colletotrichum isolates according to time

\begin{tabular}{|c|c|c|c|c|c|c|}
\hline $\begin{array}{l}\text { Time } \\
\text { (per } \\
\text { week) }\end{array}$ & Varieties & Control & Coll1 & Coll2 & Coll3 & Coll4 \\
\hline \multirow[t]{3}{*}{1} & Camarosa & $0.00^{1}$ & $4^{j^{\prime} k^{\prime} l^{\prime}}$ & $0^{1}$ & $7.33^{\text {h'i' }{ }^{\prime} j^{\prime} k^{\prime} l^{\prime}}$ & $0^{1+}$ \\
\hline & Fortuna & $0.00^{1}$ & $5.83^{\mathrm{i}^{\prime} \mathrm{j}^{\prime} \mathrm{\prime}^{\prime}}$ & $3^{\mathrm{j}^{\prime} \mathrm{k}^{\prime} \mathrm{r}}$ & $10^{\mathrm{f}^{\prime} \mathrm{g}^{\prime} \mathrm{h}^{\prime} \mathrm{i}^{\prime} \mathrm{j}^{\prime} \mathrm{k}^{\prime} \mathrm{P}^{\prime}}$ & $1.6^{\mathrm{k}^{\prime}{ }^{\prime}}$ \\
\hline & Festival & $0.00^{1}$ & $13.33^{\mathrm{f}^{\prime} \mathrm{g}^{\prime} \mathrm{h}^{\prime} \mathrm{i}^{\prime} \mathrm{j}^{\prime} \mathrm{k}^{\prime} \mathrm{l}^{\prime}}$ & $16.5^{\text {e }^{\prime} \mathrm{f}^{\prime} \mathrm{g}^{\prime} \mathrm{h}^{\prime} \mathrm{j}^{\prime} \mathrm{j}^{\prime} \mathrm{l}^{\prime}}$ & $43.33^{\text {xyza' }}$ & $18^{\text {d'e }^{\prime} \mathrm{f}^{\prime} \mathrm{g}^{\prime} \mathrm{h}^{\prime} \mathrm{i}^{\prime} \mathrm{j}^{\prime} \mathrm{\prime}}$ \\
\hline \multirow[t]{3}{*}{2} & Camarosa & $0.00^{1}$ & 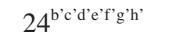 & 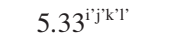 & $35^{\text {yza'b'c'd' }}$ & 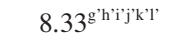 \\
\hline & Fortuna & $0.00^{1}$ & $32.66^{\mathrm{za} \mathrm{a}^{\prime} \mathrm{c}^{\prime} \mathrm{d}^{\prime} \mathrm{e}^{\prime}}$ & $25^{\text {b'c'd'e'f'g' }}$ & $48^{\mathrm{vwxyz}}$ & $17.33^{e^{e} f^{\prime} g^{\prime} h^{\prime} i^{\prime} j^{\prime} k^{\prime} l}$ \\
\hline & Festival & $0.00^{1}$ & $48^{\mathrm{vwxyz}}$ & $45.33^{\mathrm{wxyz}}$ & $65^{\text {rstuv }}$ & $50^{\text {uvwxyz }}$ \\
\hline \multirow[t]{3}{*}{3} & Camarosa & $0.00^{\mathrm{l}^{\prime}}$ & $26.66^{\mathrm{a}^{\prime} \mathrm{b}^{\prime} \mathrm{c}^{\prime} \mathrm{d}^{\prime} \mathrm{e}^{\prime} \mathrm{f}^{\prime}}$ & $22.5^{\text {c'd de'f' }^{\prime} \mathrm{g}^{\prime \prime} \mathrm{h}^{\prime}{ }^{\prime}}$ & $47.6^{\mathrm{vwxyz}}$ & $20^{\text {de }^{\prime} \mathrm{f}^{\prime} \mathrm{g}^{\prime} \mathrm{h}^{\prime} \mathrm{i}^{\prime} \mathrm{j}^{\prime}}$ \\
\hline & Fortuna & $0.00^{\mathrm{l}^{\prime}}$ & $55^{\text {tuvwxy }}$ & 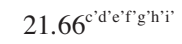 & $62^{\text {stuvw }}$ & $38.66^{\text {yza'b'c' }^{\prime}}$ \\
\hline & Festival & $0.00^{\mathrm{l}^{\prime}}$ & $14.16^{\mathrm{f}^{\prime} \mathrm{g}^{\prime} \mathrm{h}^{\prime} \mathrm{i}^{\prime} \mathrm{j}^{\prime} \mathrm{k}^{\prime} \mathrm{l}^{\prime}}$ & $40.66^{\text {xyza`b’ }}$ & $81.66^{\text {nopq }}$ & $79.33^{\text {opqrs }}$ \\
\hline \multirow[t]{3}{*}{4} & Camarosa & $0.00^{1}$ & $56.66^{\mathrm{tuvwx}}$ & $55^{\text {tuvwxy }}$ & $99^{\mathrm{klmn}}$ & $75.83^{\text {opqrs }}$ \\
\hline & Fortuna & $0.00^{1}$ & $93^{\operatorname{lmno}}$ & $82.66^{\text {nopq }}$ & $105^{\mathrm{ijklm}}$ & $66.73^{\text {qrstu }}$ \\
\hline & Festival & $0.00^{l^{\prime}}$ & $79.33^{\text {opqrs }}$ & $38.66^{\text {yza'b'c' }^{\prime}}$ & $85^{\text {mnop }}$ & $51.66^{\text {uvwxy }}$ \\
\hline \multirow[t]{3}{*}{5} & Camarosa & $0.00^{\mathrm{l}^{\prime}}$ & $70.63^{\mathrm{pqrst}}$ & $44^{\text {xyza' }}$ & $101.5^{\mathrm{jklm}}$ & $81.5^{\text {nopqr }}$ \\
\hline & Fortuna & $0.00^{1}$ & $125^{\mathrm{hi}}$ & $152^{\mathrm{g}}$ & $294^{\mathrm{c}}$ & $125.66^{\mathrm{hi}}$ \\
\hline & Festival & $0.00^{1}$ & $90.66^{\mathrm{mno}}$ & $87.83^{\mathrm{mnop}}$ & $114^{\mathrm{ijk}}$ & $70^{\mathrm{qrst}}$ \\
\hline \multirow[t]{3}{*}{6} & Camarosa & $0.00^{\mathrm{l}^{\prime}}$ & $135^{\mathrm{gh}}$ & $110^{\mathrm{ijkl}}$ & $187^{\mathrm{f}}$ & $115.5^{\mathrm{ijk}}$ \\
\hline & Fortuna & $0.00^{1}$ & $378^{\mathrm{b}}$ & $300^{c}$ & $408^{\mathrm{a}}$ & $198^{\mathrm{ef}}$ \\
\hline & Festival & $0.00^{1}$ & $209.6^{\mathrm{de}}$ & $192.6^{\text {def }}$ & $222^{\mathrm{d}}$ & $118.83^{\mathrm{hij}}$ \\
\hline
\end{tabular}

Any two data in a table followed by the same letter are not statistically different at $5 \%$ 

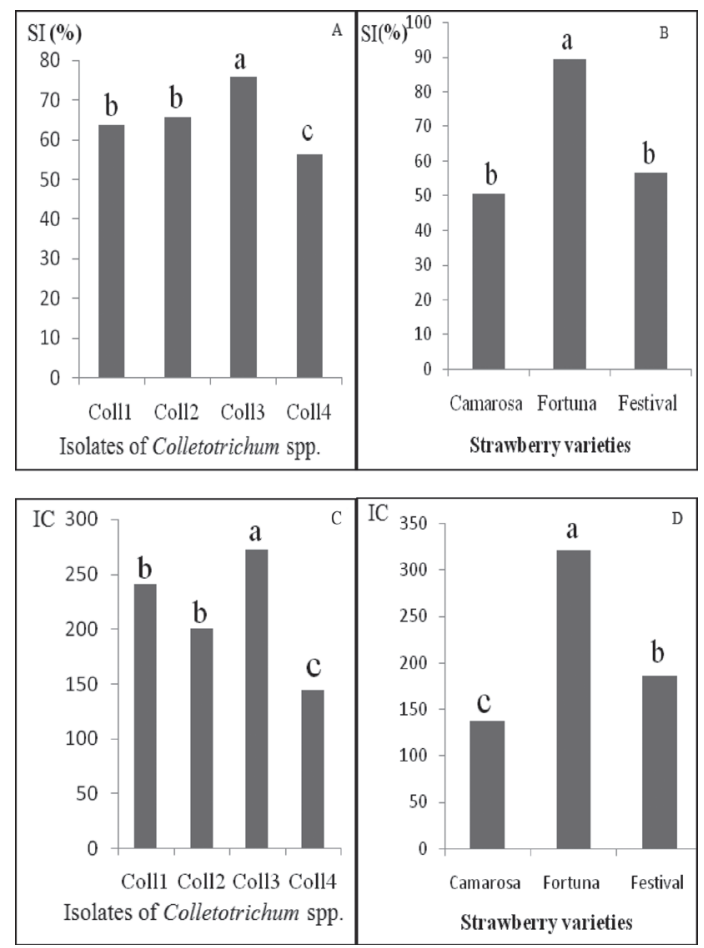

Fig. 2. Average percentage of severity index (IS) and infection coefficient (CI) in regard to Colletotrichum isolates (A and C) and the three strawberry varieties (B and D) after 6 weeks of inoculation

inoculation. In Fortuna variety inoculated with Coll3 isolate, the severity index and infection rates raised to $100 \%$ and 408 , respectively, with significant differences between tested isolates. Coll4 presented the lowest severity index (43.98\%) in Camarosa variety combined to infection coefficient of 115.5 slightly higher than that of Coll2 (110) but inferior to that of Coll1.

The results revealed that there were significant differences in disease severity between varieties. A various susceptibility levels were observed. Fortuna was the most susceptible strawberry variety to anthracnose showing higher severity index and infection coefficients rates $(89.09 \%$ - 321) compared to Camarosa (Fig. 2B and D). Similarly, the comparison of severity index and infection coefficient values gathered at the sixth week, indicate the highest aggressiveness of $C$. gleoesporioides isolate (Coll3) which was the most pathogenic (75.89\% - 272.33) (Fig. 2A and C). No symptoms were developed in the controls inoculated with sterile distilled water.

In regard of strawberry's infection, the percentage of rotten fruit had gradually increased by time. Seven days after inoculation, a weak deterioration was noted on Fortuna strawberries with the percentage of $6.66 \%$ and $8.33 \%$ in the presence of Coll2 and Coll3, respectively, while no symptoms were detected on varieties Camarosa and Festival. Four weeks after inoculation of the plants, the results revealed a significant difference between fruit reaction to isolates with a percentage of rotten fruit reaching $72.22 \%$ for Coll3 whereas those of the other isolates ranged between 30 and $37 \%$. The final disease 
level after six weeks of inoculation was more important. A maximal percentage of rotten strawberries was found on the strawberry plants inoculated with Coll3 isolate, $100 \%$ on Fortuna variety, followed by $83.33 \%$ on Festival variety and $70 \%$ on Camarosa variety but the lowest one was that of Coll1 on Festival variety (22.22\%) (Table 3).

The measurement of the growth parameters of strawberry plants inoculated with Colletotrichum species revealed a notable reduction in leaf and root fresh and dry biomass. Thus, after six weeks of artificial inoculation (Fig. 3), the fresh weight of the aerial parts had significantly decreased compared to the control plants. In the presence of the Coll3 isolate, it was in the order of $9.96 \mathrm{~g}$ in Fortuna, $13.2 \mathrm{~g}$ in Festival and $22.76 \mathrm{~g}$ in Camarosa variety compared to $25 \mathrm{~g}, 35.8 \mathrm{~g}, 22.76 \mathrm{~g}$ and $34.4 \mathrm{~g}$, respectively, in control plants. Likewise, the fresh biomass of the root system of the tested varieties inoculated by Coll3 was reduced nearly to half with respect to the control plants. It decreased, respectively, to $11.73 \mathrm{~g}$ (Fortuna); $18.53 \mathrm{~g}$ (Festival) and $19.36 \mathrm{~g}$ (Camarosa) (Table 4).

The inoculation tests had led to the reduction of the dry weights of both aerial parts and the root system of plants of the three strawberry varieties with different degrees. The Coll3 and the Coll4 isolates have caused a significant reduction of dry biomass of the aerial part of Fortuna and Festival varieties, respectively, equal to $1.86 \mathrm{~g}-3.886 \mathrm{~g}$ and

Table 3

Evolution in function of time of rotten strawberry's percentage six weeks after inoculation by Colletotrichum isolates

\begin{tabular}{|c|c|c|c|c|c|c|}
\hline $\begin{array}{l}\text { Time } \\
\text { (per } \\
\text { week) }\end{array}$ & Varieties & Control & Coll1 & Coll2 & Coll3 & Coll4 \\
\hline \multirow[t]{3}{*}{1} & Camarosa & $0.00^{\mathrm{u}}$ & $0.00^{\mathrm{u}}$ & $0.00^{\mathrm{u}}$ & $0.00^{\mathrm{u}}$ & $0.00^{\mathrm{u}}$ \\
\hline & Fortuna & $0.00^{\mathrm{u}}$ & $0.00^{\mathrm{u}}$ & $6.66^{\mathrm{tu}}$ & $8.33^{\text {stu }}$ & $0.00^{\mathrm{u}}$ \\
\hline & Festival & $0.00^{\mathrm{u}}$ & $0.00^{\mathrm{u}}$ & $0.00^{\mathrm{u}}$ & $0.00^{\mathrm{u}}$ & $0.00^{\mathrm{u}}$ \\
\hline \multirow[t]{3}{*}{2} & Camarosa & $0.00^{\mathrm{u}}$ & $0.00^{\mathrm{u}}$ & $0.00^{\mathrm{u}}$ & $24.44^{\mathrm{klmnopqrst}}$ & $16.66^{\mathrm{klmnopqrst}}$ \\
\hline & Fortuna & $0.00^{\mathrm{u}}$ & $30.66^{\text {ghijklmnop }}$ & $18.33^{\text {mnopqrstu }}$ & $36.66^{\text {ghijklmno }}$ & $22.22^{\text {lmnopqrstu }}$ \\
\hline & Festival & $0.00^{\mathrm{u}}$ & $11.11^{\text {qrst }}$ & $16.66^{\text {nopqrstu }}$ & $14.28^{\text {opqrstu }}$ & $9.52^{\text {rstu }}$ \\
\hline \multirow[t]{3}{*}{3} & Camarosa & $0.00^{\mathrm{u}}$ & $8.33 \mathrm{stu}$ & $0.00^{\mathrm{u}}$ & $24.99^{\mathrm{klmnopqrst}}$ & $20.50^{\text {mnopqrstu }}$ \\
\hline & Fortuna & $0.00^{\mathrm{u}}$ & $32.14^{\text {hijklmnopqr }}$ & $20.11^{\text {mnopqrstu }}$ & $32.22^{\text {hijklmnopq }}$ & $26.36^{\mathrm{klmnopqrst}}$ \\
\hline & Festival & $0.00^{\mathrm{u}}$ & $14.24^{\text {pqrstu }}$ & $18.33^{\text {mnopqrstu }}$ & $26.66^{\mathrm{jklmnopqrs}}$ & $26.38^{\mathrm{klmnopqrs}}$ \\
\hline \multirow[t]{3}{*}{4} & Camarosa & $0.00^{\mathrm{u}}$ & $16.66^{\text {nopqrstu }}$ & $25.00^{\mathrm{klmnopqrst}}$ & $60.91^{\text {bcdef }}$ & $44.44^{\text {efghijkl }}$ \\
\hline & Fortuna & $0.00^{\mathrm{u}}$ & $33.33^{\text {hijklmnopq }}$ & $37.40^{\text {ghijklmnop }}$ & $72.22^{\mathrm{bc}}$ & $30.28^{\text {hijklmnopqrs }}$ \\
\hline & Festival & $0.00^{\mathrm{u}}$ & $16.66^{\text {nopqrstu }}$ & $28.45^{\mathrm{ijklmnopqrst}}$ & $40.36^{\mathrm{fghijklm}}$ & $28.22^{\mathrm{ijklmnopqrst}}$ \\
\hline \multirow[t]{3}{*}{5} & Camarosa & $0.00^{\mathrm{u}}$ & $20.14^{\text {mnopqrstu }}$ & $27.3^{\mathrm{ijklmnopqrs}}$ & $66.70^{\text {bcde }}$ & $47.16^{\text {defghijk }}$ \\
\hline & Fortuna & $0.00^{\mathrm{u}}$ & $35.40^{\text {hijklmnop }}$ & $40.00^{\text {fghijklmn }}$ & $80.45^{\mathrm{ab}}$ & $32.50^{\text {hijklmnopq }}$ \\
\hline & Festival & $0.00^{\mathrm{u}}$ & $20.4^{\text {mnopqrstu }}$ & $39.15^{\text {fghijklmno }}$ & $50.40^{\text {cdefghi }}$ & $30.44^{\text {hijklmnopqrs }}$ \\
\hline \multirow[t]{3}{*}{6} & Camarosa & $0.00^{\mathrm{u}}$ & $24.26^{\mathrm{klmnopqrst}}$ & $35.36^{\text {hijklmnop }}$ & $70.25^{\text {bcd }}$ & $50.00^{\text {cdefghij }}$ \\
\hline & Fortuna & $0.00^{\mathrm{u}}$ & $60.00^{\text {bcdefg }}$ & $52.38^{\text {cdefgh }}$ & $100^{\mathrm{a}}$ & $33.33^{\text {hijklmnopq }}$ \\
\hline & Festival & $0.00^{\mathrm{u}}$ & $22.22^{\text {lmnopqrstu }}$ & $40.47^{\text {fghijklm }}$ & $83.33^{\mathrm{ab}}$ & $44.77^{\text {efghijkl }}$ \\
\hline
\end{tabular}

Any two data in a table followed by the same letter are not statistically different at $5 \%$ 

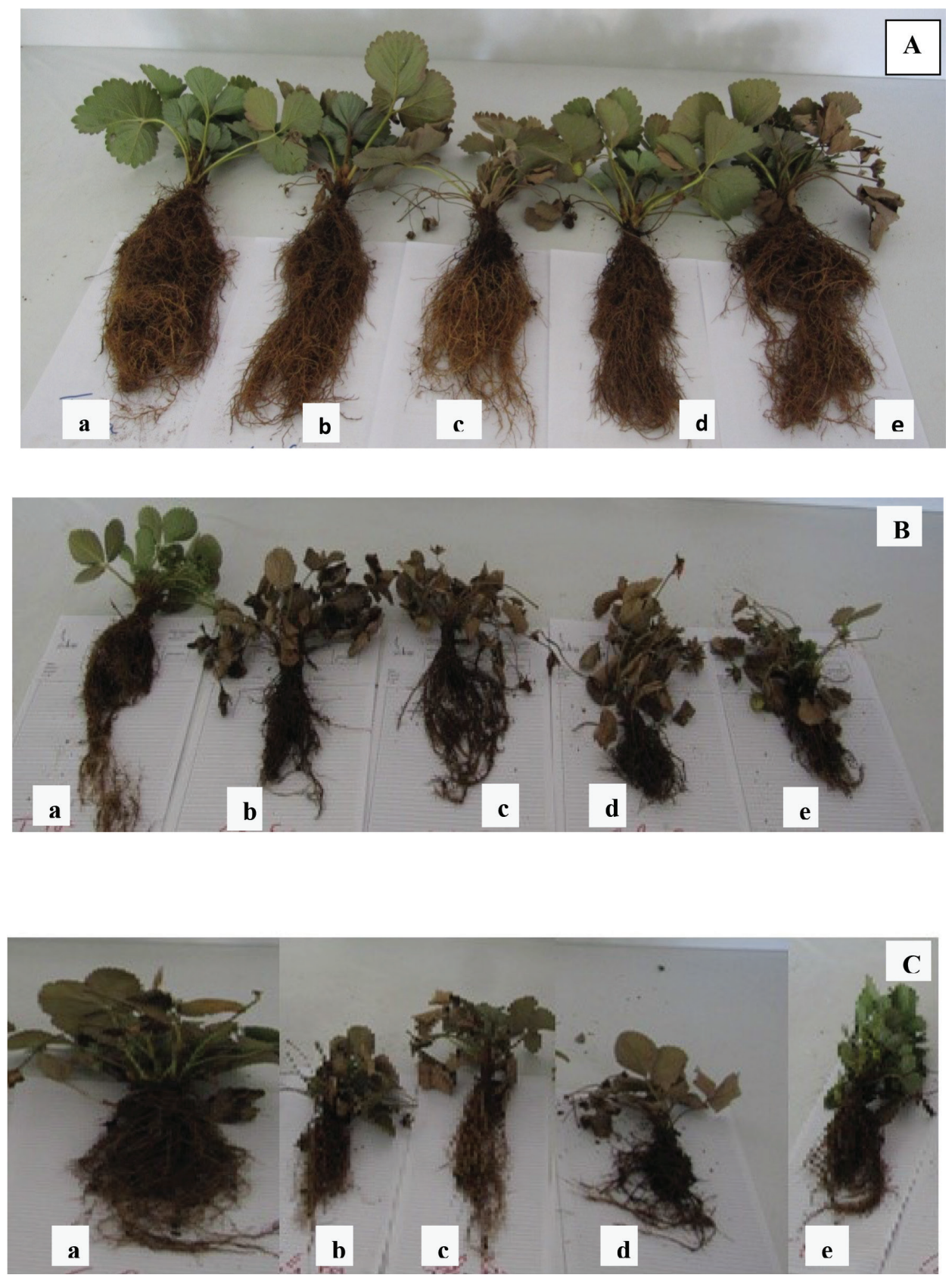

Fig. 3. Aerial parts and root system growth of three strawberry varieties, (A) Camarosa, (B) Fortuna and (C) Festival, 6 weeks after inoculation with Colletotrichum isolates Coll1 (b), Coll2 (c), Coll3 (d) and Coll4 (e) compared to control plant (a) 
$3 \mathrm{~g}-3.76 \mathrm{~g}$ while those of control plant were in order of $14.9 \mathrm{~g}$ and $10.3 \mathrm{~g}$. However, the dry weight of aerial parts of non-inoculated plants doubled those obtained in plants inoculated with Coll1 and Coll2. The aerial dry biomass of Camarosa variety inoculated with Coll3 (5.6 g) has decreased by half of that of control plants which showed a significantly identical dry biomass in the presence of the other isolates (Table 5). A considerable reduction of the dry weight biomass of the root system of strawberry plants was noted in case of inoculations by four tested Colletotrichum isolates (Table 5).

The re-isolation test was performed in order to describe whether the fungus invaded the plant. The colonization of Colletotrichum isolates of various plant organs of the strawberry varieties showed significant differences between the isolates (Table 6). The re-isolation percentage of Coll3 isolate from Fortuna variety leaves was positive and exceeded $93.33 \%$ followed by that of Coll2 $(91.17 \%)$, and Coll1 $(82.60 \%)$ whereas that of Coll4 was $46.66 \%$. The re-isolation percentage of Colletotrichum isolates from leaves on other varieties was fluctuating varying from $41.66 \%$ to $61.53 \%$.

\section{Table 4}

Effect of Colletotrichum isolates on Fresh weight of vegetative and root biomasses of strawberry plants six weeks after inoculation (expressed in $\mathrm{g}$ )

\begin{tabular}{|c|c|c|c|c|c|c|}
\hline \multirow{3}{*}{ Isolates } & \multicolumn{6}{|c|}{ Fresh weight } \\
\hline & \multicolumn{3}{|c|}{ Aerial parts } & \multicolumn{3}{|c|}{ Root parts } \\
\hline & Cam & Frt & Fst & Cam & Frt & Fst \\
\hline Control & $34.40^{\mathrm{a}}$ & $25.00^{\mathrm{ab}}$ & $35.80^{\mathrm{a}}$ & $60.5^{\mathrm{a}}$ & $22.30^{\text {cd }}$ & $42.80^{\mathrm{ab}}$ \\
\hline Coll1 & $24.66^{\mathrm{ab}}$ & $12.43^{\mathrm{bc}}$ & $19.03^{\mathrm{bc}}$ & $35.5^{\mathrm{bc}}$ & $18.53^{\text {cd }}$ & $20.93^{\mathrm{cd}}$ \\
\hline Coll2 & $23.60^{\mathrm{abc}}$ & $15.93^{\mathrm{bc}}$ & $16.03^{\mathrm{bc}}$ & $22.9^{\text {cd }}$ & $13.26^{\mathrm{d}}$ & $15.13^{\mathrm{d}}$ \\
\hline Coll3 & $22.76^{\mathrm{abc}}$ & $9.96^{\mathrm{c}}$ & $13.2^{\mathrm{bc}}$ & $19.36^{\mathrm{cd}}$ & $11.73^{\mathrm{d}}$ & $18.53^{\text {cd }}$ \\
\hline Coll4 & $26.23^{\mathrm{ab}}$ & $10.53^{\mathrm{c}}$ & $14.43^{\mathrm{bc}}$ & $29.40^{\text {bcd }}$ & $12.83^{\mathrm{d}}$ & $21.66^{\mathrm{cd}}$ \\
\hline
\end{tabular}

Varieties: Cam: Camarosa; Frt: Fortuna; Fst: Festival

For each parameter, any two data in a table followed by the same letter are not statistically different at $5 \%$

Table 5

Effect of Colletotrichum isolates on Dry weight of vegetative and root biomasses of strawberry plants six weeks after inoculation (expressed in $\mathrm{g}$ )

\begin{tabular}{|c|c|c|c|c|c|c|}
\hline \multirow{3}{*}{ Isolates } & \multicolumn{6}{|c|}{ Dry weight } \\
\hline & \multicolumn{3}{|c|}{ Aerial parts } & \multicolumn{3}{|c|}{ Root parts } \\
\hline & Cam & Frt & Fst & Cam & Frt & Fst \\
\hline Control & $10.40^{\mathrm{b}}$ & $14.90^{\mathrm{a}}$ & $10.3^{\mathrm{b}}$ & $35.20^{\mathrm{a}}$ & $14^{\mathrm{bc}}$ & $19^{\mathrm{b}}$ \\
\hline Coll1 & $10.20^{\mathrm{b}}$ & $6.02^{\text {cdef }}$ & $4.90^{\text {cdefg }}$ & $13.50^{\mathrm{bc}}$ & $8.13^{\mathrm{cd}}$ & $6.6^{\mathrm{cd}}$ \\
\hline Coll2 & $8.13^{\mathrm{bcd}}$ & $7.10^{\text {bcde }}$ & $4.46^{\mathrm{defg}}$ & $10.50^{\text {bcd }}$ & $5.93^{\mathrm{cd}}$ & $6.2^{\mathrm{cd}}$ \\
\hline Coll3 & $5.60^{\text {cdefg }}$ & $1.86^{\mathrm{g}}$ & $3.00^{\mathrm{fg}}$ & $6.63^{\mathrm{cd}}$ & $2.43^{\mathrm{d}}$ & $5.33^{\mathrm{cd}}$ \\
\hline Coll4 & $8.46^{\mathrm{bc}}$ & $3.86^{\mathrm{efg}}$ & $3.76^{\mathrm{efg}}$ & $14.26^{\mathrm{bc}}$ & $2.73^{\mathrm{d}}$ & $7.20^{\mathrm{cd}}$ \\
\hline
\end{tabular}

Varieties: Cam: Camarosa; Frt: Fortuna; Fst: Festival

For each parameter, any two data in a table followed by the same letter are not statistically different at $5 \%$ 
Table 6

Re-isolation frequencies (in \%) of Colletotrichum from different organs of strawberry plants six weeks after inoculation

\begin{tabular}{|c|c|c|c|c|c|c|c|c|c|}
\hline \multirow[t]{2}{*}{ Isolates } & \multicolumn{3}{|c|}{ Fortuna } & \multicolumn{3}{|c|}{ Festival } & \multicolumn{3}{|c|}{ Camarosa } \\
\hline & Leaves & Crowns & Roots & Leaves & Crowns & Roots & Leaves & Crowns & Roots \\
\hline Coll1 & $82.60^{\mathrm{a}}$ & $26.35^{\text {cde }}$ & $0^{\mathrm{f}}$ & $53.33^{\mathrm{b}}$ & $13.33^{\text {def }}$ & $0^{\mathrm{f}}$ & $44.44^{\mathrm{bc}}$ & $30.76^{\text {cd }}$ & $0^{\mathrm{f}}$ \\
\hline Coll2 & $91.17^{\mathrm{a}}$ & $26.45^{\text {cde }}$ & $0^{\mathrm{f}}$ & $56.25^{\mathrm{b}}$ & $7.69^{\mathrm{ef}}$ & $0^{\mathrm{f}}$ & $41.66^{\mathrm{bc}}$ & $28.57^{\mathrm{cd}}$ & $0^{\mathrm{f}}$ \\
\hline Coll3 & $93.33^{\mathrm{a}}$ & $53.33^{\mathrm{b}}$ & $0^{\mathrm{f}}$ & $58.33^{\mathrm{b}}$ & $26.66^{\text {cde }}$ & $0^{\mathrm{f}}$ & $61.53^{b}$ & $53.33^{\mathrm{b}}$ & $0^{\mathrm{f}}$ \\
\hline Coll4 & $46.66^{\mathrm{b}}$ & $26.66^{\mathrm{cde}}$ & $0^{\mathrm{f}}$ & $52.94^{\mathrm{b}}$ & $6.66^{\mathrm{ef}}$ & $0^{\mathrm{f}}$ & $42.85^{\mathrm{bc}}$ & $28.75^{\mathrm{cd}}$ & $0^{\mathrm{f}}$ \\
\hline
\end{tabular}

Any two data in a table followed by the same letter are not statistically different at $5 \%$

The highest re-isolation percentage of Coll3 isolate was obtained from Fortuna and Camarosa varieties crowns reaching $53.33 \%$ compared to $26.66 \%$ from Festival variety. A reduced re-isolation percentage of $C$. acutatum isolates (Coll1 and Coll2) were registered on Fortuna and Camarosa varieties crowns not exceeding $30.76 \%$ and superior to that noted on Festival crown (13.33\%). However, no isolate was recovered from root system of all inoculated strawberry plants (Table 6).

\section{Discussion and Conclusion}

The pathogenicity of tested Colletotrichum isolates has been evidently demonstrated. The used varieties of strawberry plants inoculated with conidial suspension of C. acutatum and one isolate of C. gloeosporioides species showed the symptoms of anthracnosis on the aerial organs as well as a decrease of the vegetative and root biomass.

Indeed, the anthracnose, which is caused by the hemibiotroph Colletotrichum spp., is one of the most destructive diseases of cultivated strawberry (Fragaria $\times$ ananassa Duchesne) worldwide (Buddie et al., 1999; Münch et al., 2008; Debode et al., 2009). In fact, various symptoms are described on different strawberry plant parts such irregular and black leaf lesions, crown rot, flower blight and fruit rot (Freeman and Katan, 1997) considered as one of the most important pre-harvest fruit diseases caused by C. acutatum (Legard et al., 2003). In Manitoba, anthracnose fruit rot caused by $C$. acutatum appeared as small, irregular, tan or light brown, water-soaked lesions that dry, and mummified later (Xue and Davidson, 1995). In comparison, this disease produce a round, hollow, brownish, then black spots, covering with small orange spots, acervuli (Roger, 1953; Smith and Black, 1990). In agreement with our outcomes, an abnormal growth of strawberries was observed when early infection affects younger fruits (Roger, 1953). In addition, attacks can occur on all over the plant, including roots, leaves, flowers, runners, and fruits causing diseases such as defoliation, blossom blight and fruit rot (Bailey and Jeger, 1992). Additionally, in the present study Colletotrichum isolates have been recovered from crowns and roots of plants that exhibit a progressive wilt reaching whole plant. Similarly, according to Smith (1998), plants with symptoms of Colletotrichum crown rot show a sudden wilt of the entire plant and eventually the entire crown becomes discolored and the plant dies (Horn and Carver, 1963; Legard, 2000). As regards to C. gloeosporioides pathogenicity, Akhter et al. (2009) announced the development of a watery, irregular blotches and 
pale brown spots 1 to $3 \mathrm{~mm}$ in diameter on strawberries, then tissues with lesions began to rot and/or blight when lesions enlarged and coalesced 6 to 8 days after inoculation. Howard and Albregts (1983) described a black leaf spot phase of strawberry caused by C. gloeosporioides which is often found in association with anthracnose symptoms on runners and petioles. In same way, the isolates of the two species tested in this study were able to damage both leaf tissues developing brown lesion in color that enlarged and dried as well as strawberries have been heavily affected by all isolates of the two species. Although, these species are pathogenic on strawberry, their survival and pathogenicity potential are not similar on the different organs of this plant. Thus, the study of the pathogenic ability of isolates originating from France showed the prevalence of $C$. acutatum on C. gloeosporioides that produced symptoms on the leaves of inoculated strawberry plants (Denoyes and Baudry, 1995). Whereas, other isolates of C. gloeosporioides have caused severe disease on strawberry leaves (Howard et al., 1992). Numerous studies have shown the ability of $C$. gloeosporioides to induce symptoms on blueberry leaves (Kim and Xiao, 2008), mango and piggyback plant (Pierce and McCain, 1990).

Based on our results of statistical evaluation, the capacity of C. acutatum isolates and $C$. gloeosporioides to infect the three varieties of strawberry plants was different. C. gloeosporioides was the most virulent and the Fortuna variety was more susceptible than the two others. Previous studies examining variation in strawberry resistance to C. fragariae or C. gloeosporioides found a broad range of susceptibility among cultivars and aggressiveness among isolates (Delp and Milholland, 1981; Smith and Black, 1990). Nowadays, there are no cultivars that exhibit complete resistance to Colletotrichum spp., thus aggravating its deleterious effects on strawberry production (Dodds and Rathjen, 2010; Amil-Ruiz et al., 2011). Many cultivated Fragaria $\times a n a n a s s a$ varieties were also characterized as the phenotypes resistant or tolerant to respective strawberry diseases in field conditions (Wing et al. 1995; Nelson et al., 1996; Bell et al., 1997; Shaw and Gordon 2003; Mori et al., 2005; Particka and Hancock, 2005; Zebrowska et al., 2006; Masny and Zurawicz, 2008). According to Seijo et al. (2008), different resistance levels were associated to strawberry cultivars currently grown in Florida. The variability of susceptibility could be related to some traits in plant. Among these, previous studies suggest that expression of resistance to $C$. acutatum disease may depend on the strain of the pathogen (Agostini et al., 1992; Chakraborty et al., 1997). Some strawberry cultivars have shown immunity to fruit rot caused by $C$. acutatum but more susceptibility to highly pathogenic isolates of Colletotrichum species that may cause a necrosis and crown rot (Delp and Milholland, 1981; Howard et al., 1992; Denoyes and Baudry, 1995; Freeman et al., 1997; Maas, 1998). The difference in resistance of strawberry cultivar to C. acutatum isolate seems to be polygenic (Denoyes and Baudry, 1995). However, the mechanisms underlying the genetic variation in the cultivated strawberry-Colletotrichum spp. interaction are largely obscure. According to Zhang et al. (2016), several PR genes were differentially expressed, with higher-amplitude changes observed in the less-susceptible cultivar which contained a higher level of basal salicylic acid defined as an extensive signaling role in plants, particularly in pathogen defense and which levels increased rapidly upon infection, followed by a sharp decrease before the necrotrophic phase. Curry et al. (2002) found that the invasion of strawberry variety tissues by $C$. acutatum and $C$. fragariae was similar; however, each invasion event occurred more rapidly with $C$. fragariae than with $C$. $a c u$ tatum whose conidial and germ tube walls and appressorium appear to modify their chitin 
distribution during initial contact with host tissue (O'Connell and Ride, 1990; Curry et al., 2002). The study of Wharton and Schilder (2008) demonstrated the ability of C. acutatum to adopt a different infection and colonization strategy depending on the susceptibility of the host tissue being colonized. In this context, results of histopathological study of Pardo et al. (2012) showed that tolerant species of strawberry to C. gloeosporioides present a noticeable accumulation of $\mathrm{H}_{2} \mathrm{O}_{2}$, a significant thickening of the cell wall in epidermal cells and changes of stomata and mesophyll cells whereas susceptible species did not and that the changes observed were correlated with the resistance to disease.

Moreover, the infection progress has led to significant adverse effects on normal growth of plants. Apparently, the inoculated strawberry plants placed in greenhouse and followed during 6 weeks showed a decrease of growth parameters as fresh and dry biomass of aerial parts and root system. According to Ndoutoume-Ndong (2007), the primary consequence of Colletotrichum gloeosporioides anthracnose on the rubber tree is the decrease in leaf area, leaf necrotic lesions and leaf fall thus reducing the plant's ability to synthesize organic matter following the decrease in photosynthesis. In accordance with our findings, the negative impact of Colletotrichum attack on plant growth parameters has also been visualized subsequent to potato roots infection leading to a poor plant emergence, growth, and early senescence (Dashwood et al., 1993). Also, tuber infection by C. coccodes producing severely affected seed yielded significantly less than healthy seeds (Read and Hide, 1995). Similarly, Nitzan et al. (2008) mentioned that plants grown from infected tubers had reduced yields even though they produced similar numbers of tubers as the non-inoculated plants.

In summary, the three varieties of strawberry plants were susceptible to Colletotrichum acutatum and C. gloeosporioides isolates responsible for anthracnose disease, among these varieties the Fortuna was the most susceptible. In addition, all isolates tested were able to cause symptoms on strawberry plants even though in varying degrees and reduce their agronomic parameters. It is necessary to think about using resistant varieties and to apply preventive and effective measures to prevent or reduce spread of these pathogens which constitute major threats not only for strawberry, but also for other economically important fruit crops, vegetables and fruits during pre- and postharvest period.

\section{Literature}

Abdel-Sattar, M. A., El-Marzoky, H. A. and Mohamed, A. I. (2008): Occurrence of soilborne diseases and root knot nematodes in strawberry plants grown on compacted rice straw bales compared with naturally infested soil. J. Plant Protection Research 48, 223-235.

Adaskaveg, J. E. and Hartin, R. J. (1997): Characterization of Colletotrichum acutatum isolates causing anthracnose of almond and peach in California. Phytopathology 87, 979-987.

Agostini, J. P., Timmer, L. W. and Mitchell, D. J. (1992): Morphological and pathological characteristics of strains of Colletotrichum gloeosporioides from Citrus. Phytopathology 82, 1377-1382.

Akgül, D. S., Awan, Q. N., Güler, P. G. and Önelge, N. (2016): First report of anthracnose and stem end rot diseases caused by Colletotrichum gloeosporioides and Neofusicoccum australeon avocado fruits in Turkey. Plant Dis. 100, 1792 p.

Akhter, Md. S., Shahidul, A. S., Shafiqul, Md. I. S. and Lee, M. W. (2009): Identification of the fungal pathogen that causes strawberry anthracnose in Bangladesh and evaluation of in vitro fungicide activity. Mycobiology $37,77-81$. 
Amil-Ruiz, F., Blanco-Portales, R., Muñoz-Blanco, J. and Caballero, J. L. (2011): The strawberry plant defense mechanism: A molecular review. Plant Cell Physiol. 52, 1873-1903.

Anonymous (2006): Diagnostic Xanthomonas fragariae. EPPO Bulletin 36, 135-144.

Anonymous (2014): Note de veille-Filière fruits rouges. Ministère de l'Agriculture et de la Pêche Maritime Direction de la Stratégie et des Statistiques. Note stratégique n 100, 1-17.

Anonymous (2015): Berry steady progress. Spécial Fruit Logistica, Agriculture du Maghreb 20-22.

Anonymous (2017): Morocco: Strawberry acreage grows from 10 to 3,660 hectares in 27 years. URL: http:// www.freshplaza.com/article/186317/Morocco-Strawberry-acreage-grows-from-10-to-3,660-hectares-in27-years

Arauz, L. F. (2000): Mango anthracnose: Economic impact and current options from integrated management. Plant Disease 84, 600-611.

Atta Aly, M. and Ezzat, M. A. (1999): Reducing quality loss of strawberries during local marketing and exportation by using different cool chains. In: D. Gerasopoulos (ed.): Post-harvest Losses of Perishable Horticultural Products in the Mediterranean Region. Chania : CIHEAM-IAMC, Cahiers Options Méditerranéennes 42, 35-47.

Bailey, J. A. and Jeger, M. J. (eds): (1992): Colletotrichum: Biology, Pathology and Control. CAB International, Wallingford, UK. 388 p.

Bell, J. A., Simpson, D. W. and Harris, D. C. (1997): Development of a method for screening strawberry germplasm for resistance to Phytophthora cactorum. Acta Hort. 439, 175-180.

Benyahia, H., Jrifi, A., Smaili, C., Afellah, M. and Timmer, L. W. (2003): First report of Colletotrichum gloeosporioides causing wither tip on twigs and tear stain on fruit of citrus in Morocco. Plant Pathol. 52, 798.

Buddie, A., Martínez-Culebras, P., Bridge, P., García, M., Querol, A., Cannon, P. and Monte, E. (1999): Molecular characterization of Colletotrichum strains derived from strawberry. Mycological Research 103, 385-394.

Bull, C. T., Huerta, A. I. and Koike, S. T. (2009): First report of blossom blight of strawberry (Fragaria $\times$ ananassa) caused by Psendomonas marginalis. Plant Disease 93, 1350.

Calleja, E. J., Ilbery, B., Spence, N. J. and Mills, P. R. (2012): The effectiveness of phytosanitary controls in preventing the entry of Colletotrichum acutatum in the UK strawberry sector. Plant Pathology 62, 266-278.

Ceja-Torres, L. F., Mora-Aguilera, G. and Mora-Aguilera, A. (2014): Agronomical management influence on the spatiotemporal progress of strawberry dry wilt in Michoacán, Mexico. African J. Agricultural Research 9, 513-520.

Chakraborty, S., Perrott, R., Charchar, M. J., Fernandes, C. D. and Kelemu, S. (1997): Biodiversity, epidemiology and virulence of Colletotrichum gloeosporioides. II. Genetic and pathogenic diversity in isolates of Colletotrichum gloeosporioides form eight species of Stylosanthes. Tropical Grasslands J. 31, 393-401.

Chattaoui, M., Raya, M. C., Bouri, M., Moral, J., Perez-Rodriguez, M., Trapero, A., Msallem, M. and Rhouma, A. (2016): Characterization of a Colletotrichum population causing anthracnose disease on Olive in northern Tunisia. J. Appl. Microbiol. 120, 1368-1381.

Chrys, N. A. (2006): Mango anthracnose disease: Present status and future research priorities. Plant Pathology J. 5, 266-273.

Curry, K. J., Abril, M., Avant, J. B. and Smith, B. J. (2002): Strawberry anthracnose: Histopathology of Colletotrichum acutatum and C. fragariae. Phytopathology 92, 1055-1063.

Darrow, G. M. (1966): The Strawberry; History, Breeding and Physiology (1st ed.). Holt, Rinehart and Winston, New York, $555 \mathrm{p}$.

Dashwood, E. P., Fox, R. A. and Duncan, J. M. (1993): Effect of substrate and plant maturity on the incidence of infection of potato roots by pathogenic and nonpathogenic fungi. Mycological Research 97, 733-745.

De Los Santos, B., Barrau, C. and Romero, F. (2003): Strawberry fungal diseases. Food, Agriculture and Environment $1,129-132$.

Dean, R., Van Kan, J. A. L., Pretorius, Z. A., Hammond-Kosack, K. E., Di Pietro, A., Spanu, P. D., Rudd, J. J., Dickman, M., Kahmann, R., Ellis, J. and Foster, G. D. (2012): The top 10 fungal pathogens in molecular plant pathology. Mol. Plant Pathol. 13, 414-430.

Debode, J., Hemelrijck, W., Baeyen, S., Creemers, P., Heungens, K. and Maes, M. (2009): Quantitative detection and monitoring of Colletotrichum acutatum in strawberry leaves using real-time PCR. Plant Pathology $58,504-514$. 
Delp, B. R. and Milholland, R. D. (1981): Susceptibility of strawberry cultivars and related species to Colletotrichum fragariae. Plant Dis. 65, 421-423.

Denoyes, B. and Baudry, A. (1995): Species identification and pathogenicity study of French Colletotrichum strains isolated from strawberry using morphological and cultural characteristics. Phytopathology 85 , 53-57.

Dodds, P. N. and Rathjen, J. P. (2010): Plant immunity: Towards an integrated view of plant pathogen interactions. Nat. Rev. Genet. 11, 539-548.

Embaby, E. M., Ragab, M. E., Doug Doud, Kh. A. Al., Ahmed, R., Zveibil, A., Maymon, M. and Freeman, S. (2009): First report of Colletotrichum acutatum and C. gloeosporioides causing anthracnose diseases on strawberry in Egypt. New Disease Reports 20, 20.

Evenhuis, A. and Wanten, P. J. (2006): Effect of polythene tunnels and cultivars on grey mould caused by Botrytis cinerea in organically grown strawberries. Agric. Conspec. Sci. 71, 111-114.

Fang, X. D., Kuo, J., You, M. P., Finnegan, P. M. and Barbetti, M. J. (2012): Comparative root colonization of strawberry cultivars Camarosa and Festival by f. sp. fragariae. Plant and Soil 358, 75-89.

Fitzell, R. D. (1979): Colletotrichum acutatum as a cause of anthracnose of mango in New-South-Wales. Plant Dis. Rep. 63, 1067-1070.

Förster, H. and Adaskaveg, J. E. (1999): Identification of subpopulations of Colletotrichum acutatum and epidemiology of almond anthracnose in California. Phytopathology 89, 1056-1065.

Freeman, S. (2000): Genetic diversity and host specificity of Colletotrichum species on various fruits. In: D. Prusky, S. Freeman and M. B. Dickman (eds): Colletotrichum: Host Specificity, Pathology and Hostpathogen Interaction. The American Phytopathological Society. St. Paul MN., pp 131-144.

Freeman, S. and Katan, T. (1997): Identification of Colletotrichum species responsible for anthracnose and root necrosis of strawberry in Israel. Phytopathology 87, 516-521.

Freeman, S., Nizani, Y., Dotan, S., Even, S. and Sando, T. (1997): Control of Colletotrichum acutatum in strawberry under laboratory, greenhouse and field conditions. Plant Disease 81, 749-752.

Galletta, G. J. and Bringhurst, R. S. (1990): Strawberry management. In: G. J. Galletta and D. G. Himelrich (eds): Small Fruit Crop Management. Prentice-Hall Inc., New Jersey, USA, pp. 83-156.

Garrido, C., Carbu, M., Fernandez-Acero, F. J., Budge, G., Vallejo, I., Colyer, A. and Cantoral, J. M. (2008): Isolation and pathogenicity of Colletotrichum spp. causing anthracnose of strawberry in South-West Spain. European J. Plant Pathology 120, 409-415.

Gauhl, F., Pasberg-Gauhl, C., Vuylsteke, D. and Ortiz, R. (1995): Multilocational evaluation of black Sigatoka resistance in banana and plantain. IITA Research Guide 47. 2nd edition. Training Program, International Institute of Tropical Agriculture (IITA), Ibadan, Nigeria. 59 p.

Grijalba, C. M., Pérez-Trujillo, M. M., Diana Ruiz, D. and Ferrucho, A. M. (2015): Strawberry yields with high-tunnel and open-field cultivations and the relationship with vegetative and reproductive plant characteristics. Agronomía Colombiana 33, 147-154.

Gunnell, P. S. and Gubler, W. D. (1992): Taxonomy and morphology of Colletotrichum species pathogenic to strawberry. Mycologia 84, 157-165.

Han, Y. C., Zeng, X. G., Xiang, F. Y., Ren, L., Chen, F. Y. and Gu, Y. C. (2016): Distribution and characteristics of Colletotrichum spp. associated with anthracnose of strawberry in Hubei. China. Plant Dis. 100, 996-1006.

Horn, N. L. and Carver, R. G. (1962): Anthracnose and powdery mildew on strawberry plants in Louisiana. Plant Dis. Rep. 46, 591-592.

Horn, N. L. and Carver, R. G. (1963): A new crown rot of strawberry plants caused by Colletotrichum fragariae. Phytopathology 53, 768-770.

Howard, C. M. (1972): A strawberry fruit rot caused by Colletotrichum fragariae. Phytopathology 60, 600-602.

Howard, C. M. and Albregts, E. E. (1983): Black leaf spot phase of strawberry anthracnose caused by Colletotrichum gloesporiodes (= fragariae). Plant Dis. 67, 1144-1146.

Howard, C. M., Maas, J. L., Chandler, C. K. and Albregts, E. E. (1992): Anthracnose of strawberry caused by the Colletotrichum complex in Florida. Plant Dis. 76, 976-981.

Hummer, K. and Hancock, J. F. (2009): Strawberry genomics: botanical history, cultivation, traditional breeding, and new technologies. In: K. Folta and S. Gardiner (eds): Genetics and Genomics of Rosaceae. Springer Science + Business Media, New York, pp. 413-436. 
Jensen, M. H. and Malter, A. J. (1995): Protected agriculture: a global review. Technical Papel No. 253. World Bank, Washington DC.

Jiang, W. J., Qu, D. Y., Mu, D. and Wang, L. R. (2003): Protected cultivation of horticultural crops in China. Hortic. Rev. 30, 115-162.

Kadir, S., Carey, E. and Ennahli, S. (2006): Influence of high tunnel and field conditions on strawberry growth and development. HortScience 41, 329-335.

Kim, Y. K. and Xiao, C. L. (2008): Distribution and incidence of Sphaeropsis rot in apple in Washington State. Plant Disease 92, 940-946.

Kosar, M., Kafkas, E., Paydas, S., Hüsnü, K. and Baser, C. (2004): Phenolic composition of strawberry genotypes at different maturation stages. J. Agric. Food Chem. 52, 1586-1589.

Lagziri, M. and El Amrani, A. (2009): Effect of a microbial based acaricidal product on spotted and predatory spidermites. African Crop Sciences J. 17, 111-123.

Lamindia, J. A. (2002): Seasonal populations of Pratylenchus penetrans and Meloidogyne hapla in strawberry roots. J. Nematology 34, 409-413.

Lamont, Jr. W. J. (2009): Overview of the use of high tunnels worldwide. HortTechnology, 19, 25-29.

Lansari, A. (1985): Chemical weed control and effect of herbicides in strawberry (cv. Tioga) plantation in Morocco. Revue Horticole 257, 27-30.

Legard, D. E. (2000): Colletotrichum diseases of strawberry in Florida. In: D. Prusky, S. Freeman and M. B. Dickman (eds): Colletotrichum: Host Specificity, Pathology and Host-pathogen Interactions. American Phytopathological Society Press, St. Paul, MN, USA, pp. 292-299.

Legard, D. E., Ellis, M. A., Chandler, C. K. and Price, J. F. (2003): Integrated management of strawberry diseases in winter fruit production areas. In: N. F. Childers (ed.): The Strawberry. Dr. Norman F. Childers Publications, Gainesville, FL., pp. 111-124.

Li, L. and Yang, H. (2011): First report of strawberry necrotic virus in China. Plant Dis. 95, 1198.

Lieten, F. and Baetes, W. (1991): Greenhouse strawberry culture in peat bags. Adv. Strawberry Production 10, 56-57.

López-Aranda, J. M. (2008): The cultivation of the strawberry in Huelva. In: J. de Andalucía (ed.): The Strawberry Crop at Huelva. Ideas, Exclusivas y Publicidad S.L., Sevilla (Spain), pp. 101-174.

Maas, J. L. (1998): Compendium of strawberry diseases. (2nd ed.), The American Phytopathological Society, Minnesota. 128 page

MacKenzie, S. J., Legard, D. E., Timmer, L. W., Chandler, C. K. and Peres, N. A. (2006): Resistance of strawberry cultivars to crown rot caused by Colletotrichum gloeosporioides isolates from Florida is nonspecific. Plant Dis. 90, 1091-1097.

Mangandi, J., Perez, N. A. and Whitaker, V. M. (2015): Identifying resistance to crown rot caused by Colletotrichum gloeosporioides in strawberry. Plant Dis. 99, 954-961.

Martin, M. P. and García-Figueres, F. (1999): Colletotrichum acutatum and C. gloeosporioides caused anthracnose on olives. European J. Plant Pathology 105, 733-745.

Martin, R. R., Tzanetakis, I. E., Barnes, J. E. and Elmhirst, J. F. (2004): First report of strawberry latent ring spot virus in strawberry in United States and Canada. Plant Dis. 88, 575.

Masny, A. and Zurawicz, E. (2008): Susceptibility of new dessert strawberry cultivars to Verticillium wilt. Zesz. Nauk. Inst. Sad. Kwiac 16, 249-255.

Mdarhri, M. (2005): Isolement et identification de 1'agent responsable de la maladie bactérienne des tâches angulaires du fraisier (Xanthomonas fragariae). Thèse 3ème Cycle Agronomie, Option Phytiatrie, Complexe Horticole, Institut Agronomique et Vétérinaire Hassan II, Agadir (Maroc), 38 p.

Mori, T., Kitamura, H. and Kuroda, K. (2005): Varietal differences in Fusarium wilt-resistance in strawberry cultivars and the segregation of this trait in F1 hybrids. J. Jap. Soc. Hortic. Sci. 74, 57-59.

Mouden, N. (2015): Etude de la situation phytosanitaire du fraisier (Fragaria×ananassa L.) au Maroc. Diversité fongique, pouvoir pathogène et recherche des moyens de lutte. Thèse de Doctorat, Université Ibn Tofail, Faculté des Sciences, Kenitra, Maroc, 305 p.

Mouden, N., Benkirane, R., Ouazzani Touhami, A. and Douira, A. (2013): Mycoflore de quelques variétés du fraisier (Fragaria×ananassa L.), cultivées dans la région du Gharb et le Loukkos (Maroc). J. Appl. Biosciences 61, 4490-4514. 
Mouden, N., Al Batnan, A., Benkirane, R., Ouazzani Touhami, A. and Douira, A. (2016): Diversity and distribution of fungi from strawberry plants grown in Gharb-Loukkos (Morocco). International J. Recent Scientific Research 7, 13630-13641.

Msairi, S., Chliyeh, M., Rhimini, Y., Selmaoui, K., Mouria, M., Ouazzani Touhami, A., Benkirane, R. and Douira, A. (2017): First Report on Colletotrichum acutatum of Olives in Morocco. Annual Research and Review in Biology 16, 1-8.

Münch, S., Lingner, U. and Floss, D. S. (2008): The hemibiotrophic lifestyle of Colletotrichum species. J. Plant Physiol. 165, 41-51.

Ndoutoume-Ndong, A. (2007): Importance de l'association de clones d'hévéas dans l'amélioration de la production du caoutchouc en plantations industrielles au Gabon Tropicultura 25, 66-69.

Nelson, M. D., Gubler, W. D. and Shaw, D. W. (1996): Relative resistance of 47 strawberry cultivars to powdery mildew in California greenhouse and field environments. Plant Dis. 80, 326-328.

Neri, D., Baruzzi, G., Massetani, F. and Faedi, W. (2012): Strawberry production in forced and protected culture in Europe as a response to climate change. Can. J. Plant Sci. 92, 1021-1036.

Nicolov, P. (2006): Study on the fauna of the strawberry. V. Survey of the strawberry fauna. Ecology and Future. Bulgarian J. Ecol. Sci. 5, 38-40.

Nitzan, N., Cummings, T. F. and Johnson, D. A. (2008): Disease potential of soil- and tuberborne inocula of Colletotrichum coccodes and black dot severity on potato. Plant Dis. 92, 1497-1502.

O'Connell, R. J. and Ride, J. P. (1990): Chemical detection and ultrastructural localization of chitin in cell walls of Colletotrichum lindemuthianum. Physiol. Mol. Plant Pathol. 37, 39-53.

Ogawa, J. M. and English, H. (1991): Diseases of temperate zone tree fruit and nut crops. In: University of California, Division of Agriculture and Natural Resources, Oakland, CA, pp. 345-461.

Pardo, E. M., Grellet, C. F., Salazar, S. M., Castagnaro, A. P., Díaz Ricci, J. C. and Arias, M. E. (2012): Histopathology of the resistance to Colletotrichum gloeosporioides of wild strawberries and species related to commercial strawberry. Australian J. Crop Science 6, 1147-1153.

Particka, C. and Hancock, J. F. (2005): Field evaluation of strawberry genotypes for tolerance to black root rot on fumigated and nonfumigated soil. J. Am. Soc. Hortic. Sci. 130, 688-693.

Paulus, A. O. (1990): Fungal diseases of strawberry. J. HortSci. 25, 885-889.

Pierce, L. and McCain, A. H. (1990): Anthracnose of piggyback plant caused by Colletotrichum gloeosporioides (Penz.) Sacc. J. Environ. Hort. 8, 207-209.

Prusky, D. (1996): Pathogen quiescence in postharvest diseases. Annu. Rev. Phytopathol. 34, 413-434.

Prusky, D. and Plumbey, R. A. (1992): Quiescent infections of Colletotrichum in tropical and subtropical fruit. In: J. A. Bailey, and M. J. Jeger (eds): Colletotrichum: Biology, Pathology and Control. CAB International, Wallingford, UK, pp. 289-307.

Read, P. J. and Hide, G. A. (1995): Development of black dot disease (Colletotrichum coccodes (Wallr.) Hughes) and its effect on the growth and yield of potato plants. Annals of Appl. Biol. 127, 57-72.

Roger, L. (1953): Phytopathologie des pays chauds Tome II, Paul Lechevalier Paris. 1130 p.

Rubio, S. A., Alfonso, A. M., Grijalba, C. M. and Pérez, M. M. (2014): Determinación de los costos de producción de la fresa cultivada a campo abierto y bajo macrotúnel. Rev. Colomb. Cienc. Hortic. 8, 67-79.

Schilder, A. M. C., Gillett, J. M. and Sysak, R. W. (2001): Evaluation of fungicides for control of anthracnose fruit rot of blueberries. Fungicide and Infanticide Tests 2001: SMF5.

Seijo, R., Chandler, C. K., Mertely, J. C., Moyer, C. and Peres, N. A. (2008): Resistance of strawberry cultivars and advanced selections to anthracnose and botrytis fruit rots. Proc. Fla. State Hort. Soc. 121, 246-248.

Shaw, D. V. and Gordon, T. R. (2003): Genetic response for reaction to Verticillium wilt in strawberry with two stage family and genotypic selection. HortSci. 38, 432-434.

Smith, B. J. (1986): First report of Colletotrichum acutatum on strawberry in the United States. Plant Dis. 70, 1074.

Smith, B. J. (1998): Anthracnose crown rot. In: J. L. Mass (ed.): Compendium of Strawberry Diseases. 2nd ed. American Phytopathological Society, St. Paul, MN, pp. 46-48.

Smith, B. J., Black, L. L. (1990): Morphological, cultural, and pathogenic variation among Colletotrichum species isolated from strawberry. Plant Dis. 74, 69-76.

Smith, B. J., Magee, J. B. and Gupton, C. L. (1996): Susceptibility of rabbiteye blueberry cultivars to postharvest diseases. Plant Dis. 80, 215-218. 
Sreenivasaprasad, S. and Talhinhas, P. (2005): Genotypic and phenotypic diversity in Colletotrichum acutatum, a cosmopolitan pathogen causing anthracnose on a wide range of hosts. Molecular Plant Pathol. 6, 361-378.

Talubnak, C. and Soytong, K. (2010): Biological control of Vanilla anthracnose using Emericella nidulans. International J. Agricultural Technology 6, 47-55.

Tanji, A., Benicha M. and Mamdouh, M. (2014): Technique de production de fraisier. Transfert de Technologie en Agriculture 201, 1-9.

Timmer, L. W. and Brown, G. E. (2000): Biology and control of anthracnose diseases of citrus. In: D. Prusky, S. Freeman and M. B. Dickman (eds): Colletotrichum: Host Specificity, Pathology and Host-Pathogen Interaction. The American Phytopathological Society, St. Paul, MN, pp. 300-316.

Urena-Padilla, A. R., Mackenzie, S. J., Bowen, B. W. and Legard, D. E. (2002): Etiology and population genetics of Colletotrichum spp. causing crown and fruit rot of strawberry. Phytopathology 92, 1245-1252.

Van Hemelrijck, W., Debode, J., Heungens, K., Maes, M. and Creemers, P. (2010): Phenotypic and genetic characterization of Colletotrichum isolates from Belgian strawberry fields. Plant Pathology 59, 853-861.

Voca, S., Jakobek, L., Druzica, J., Sindrak, Z., Dobricevic, N., Seruga, M. and Kovac, A. (2009): Quality of strawberries produced applying two different growing systems. CyTA - J. Food 7, 201-207.

Wharton, P. S. and Schilder, A. C. (2008): Novel infection strategies of Colletotrichum acutatum on ripe blueberry fruit. Plant Pathology 57, 122-134.

Winardiantika, V., Lee Y. H., Park, N. I. and Yeoung, Y-R. (2015): Effects of cultivar and harvest time on the contents of antioxidant phytochemicals in strawberry fruits. Hortic. Environ. Biotechnol. 56, 732-739.

Wing, K. B., Pritts, M. P. and Wilcox, W. F. (1995): Biotic, edaphic and cultural factors associated with strawberry black root rot in New York. HortScience 30, 86-90.

Wittwer, S. H. and Castilla, N. (1995): Protected cultivation of horticultural crops worldwide. HortTechnol. 5, 6-23.

Xiao, C. L., Chandler, C. K., Price, J. F., Duval, J. R., Mertely, J. C. and Legard, D. E. (2001): Comparison of epidemics of botrytis fruit rot and powdery mildew of strawberry in large plastic tunnel and field production systems. Plant Dis. 85, 901-909.

Xue, A. G. and Davidson, C. G. (1995): Occurrence of anthracnose fruit rot caused by Colletotrichum acutatum on day-neutral strawberries in Manitoba. Canadian Plant Disease Survey 75, 185-190.

Yoshida, S. and Tsukiboshi, T. (2002): Shoot blight and leaf spot of blueberry anthracnose by Colletotrichum acutatum. J. General Plant Pathol. 68, 246-248.

Zahdali, G. (2003): Evaluation des niveaux de résistance de Tetranychus urticae Koch à différents acaricides d’usage fréquents sur fraisier à Loukkos. Mémoire 3ème Cycle Institut Agronomique et Vétérinaire Hassan II, Rabat, 125 p.

Zaitlin, B., Zehr, E. I. and Dean, R. A. (2000): Latent infection on peach caused by Colletotrichum gloeosporioides and by Colletotrichum acutatum. Canadian J. Botany 22, 224-228.

Zebrowska, J., Hortyński, J., Cholewa, T. and Honcz, K. (2006): Resistance to Verticillium dahliae (Kleb.) in the strawberry breeding lines. Commun. Agric. Appl. Biol. Sci., 71, 1031-1036.

Zhang, Q-Y., Zhang, L-Q., Song, L-L., Duan, K., Li, N., Yan-Xiu Wang, Y-X. and Gao, Q-H. (2016): The different interactions of Colletotrichum gloeosporioides with two strawberry varieties and the involvement of salicylic acid. Horticulture Research 3, 1-10.

Zulfiqar, M., Brlansky, R. H. and Timmer, L. W. (1996): Infection of flower and vegetative tissues of citrus by Colletotrichum acutatum and C. gloeosporioides. Mycologia, 88, 121-128. 